\title{
JPEB
}

Jurnal Penelitian Ekonomi dan Bisnis, 4 (2), 2019, Hal: 132-142

http://www.jpeb.dinus.ac.id

\section{FAKTOR-FAKTOR PENENTU DANA PIHAK KETIGA BANK UMUM SYARIAH DI INDONESIA TAHUN 2010-2017}

\author{
Agusti Nia Aghnawati ${ }^{1}$ dan Malik Cahyadin ${ }^{2 *}$ \\ 1,2Program Studi Ekonomi Pembangunan FEB UNS \\ Jalan Ir. Sutami 36A Kentingan Kota Surakarta Provinsi Jawa Tengah \\ *Corresponding Email : malikcahyadin@gmail.com
}

Diterima: Mei 2019; Direvisi: Agustus 2019; Dipublikasikan: September 2019

\begin{abstract}
The development of third-party funds of Islamic commercial banks tends to be increasing every year. This situation is expected to be relevant with the increase of their financial performance. This study aims to analyze the factors that influence the third-party funds of Islamic commercial banks in Indonesia in 2010-2017. For the data analysis method, panel data is used with Random Effect Model (REM). This method is considered as the best one based on Chow Test, Hausman Test, and Lagrange Multiplier Test. The data consist of 8 years of time series and cross sections comprise of 10 Islamic commercial banks. Research data sources are obtained from Bank Indonesia and the Financial Service Authority. The independent variables are profit-sharing, promotion costs and the number of offices. The results of this study indicate that during research period the profit-sharing, number of offices and promotion costs give a positive and significant effect on the third-party funds of Islamic commercial banks. In addition, the coefficient of determination $\left(R^{2}\right)$ equals 0,869811. This shows that 86,9811\% of the variation of the dependent variables is explained by variation of the independent variables. Thus, Islamic commercial banks can review the value (rate) of profit-sharing, promotion costs and the number of offices to increase the value of third-party funds progressively.
\end{abstract}

Keywords: Islamic Commercial Bank; Third-Party Funds; REM

\begin{abstract}
ABSTRAK
Perkembangan dana pihak ketiga (DPK) Bank Umum Syariah (BUS) cenderung meningkat setiap tahun. Peningkatan ini diharapkan relevan dengan peningkatan kinerja keuangan usahanya. Penelitian ini bertujuan untuk menganalisis faktor-faktor yang mempengaruhi dana pihak ketiga Bank Umum Syariah di Indonesia pada tahun 2010-2017. Metode analisis data menggunakan data panel dengan Random Effect Model (REM). Metode ini dipilih sebagai model terbaik berdasarkan Uji Chow, Uji Hausman, dan Uji Lagrange Multiplier. Data penelitian ini terdiri atas time series sebanyak 8 tahun dan cross section sebanyak 10 BUS. Sumber data penelitian diperoleh dari Bank Indonesia (BI) dan Otoritas Jasa Keuangan (OJK). Variabel independen dalam penelitian ini adalah bagi hasil, biaya promosi, dan jumlah kantor layanan. Hasil penelitian ini menunjukkan bahwa selama periode penelitian bagi hasil, jumlah kantor layanan, dan biaya promosi berpengaruh positif dan signifikan terhadap DPK BUS. Selain itu, hasil uji koefisien determinasi $\left(\mathrm{R}^{2}\right)$ yaitu sebesar 0.869811. Hal tersebut menunjukkan bahwa sebesar $86.9811 \%$ variasi variabel dependen dijelaskan oleh variasi variabel independen. Untuk itu, BUS dapat mengkaji ulang penetapan tingkat bagi hasil, biaya promosi dan jumlah kantor layanan untuk mendorong capaian dana pihak ketiga secara progresif.
\end{abstract}

Kata-Kata Kunci: Bank Umum Syariah; Dana Pihak Ketiga; REM 


\section{PENDAHULUAN}

Beberapa penelitian tentang faktor-faktor yang mempengaruhi dana pihak ketiga bank umum syariah di Indonesia dilakukan oleh Mumtazah \& Septiarini (2016) dan Wulandari \& Aisjah (2014) menjelaskan bahwa bagihasil berpengaruh signifikan terhadap dana pihak ketiga. Namun Novianto \& Hadiwidjojo (2013) menemukan bahwa bagi hasil tidak signifikan. Selain itu, Mumtazah \& Septiarini (2016) juga mendeskripsikan bahwa biaya promosi berpengaruh terhadap dana pihak ketiga bank umum syariah. Sementara itu, Prasetya, Tan \& Delis (2015), dan Novianto \& Hadiwidjojo (2013) menemukan bahwa jumlah kantor layanan berpengaruh terhadap tingkat dana pihak ketiga bank umum syariah. Temuan yang berbeda dilakukan oleh Wulandari \& Aisjah (2014) bahwa jumlah kantor layanan tidak berpengaruh terhadap dana pihak ketiga bank umum syariah.

Novianto \& Hadiwidjojo (2013) mengidentifikasi bahwa PDB berpengaruh terhadap dana pihak ketiga bank umum syariah. Selain itu, Yulianto \& Sholikhah (2016) menjelaskan bahwa Non Performing Financing (NPF) berpengaruh terhadap dana pihak ketiga. Mobin \& Masih (2014) mendeskripsikan bahwa inflasi berdampak signifikan terhadap tabungan di bank Islam sedangkan GDP dan Kuala Lumpur composite index tidak signifikan. Sementara itu, Hilman (2016) menyimpulkan bahwa profit-sharing rate, interest rate, Jakarta Islamic Index (JII), and GDP berpengaruh signifikan terhadap Mudharabah Deposit.

Sari, Wibowo \& Suprapto (2015) berpendapat bahwa faktor penting dalam mendorong masyarakat perdesaan menjadi nasabah bank Islam adalah orang berpengaruh yang dipercaya oleh masyarakat untuk meyakinkan mereka tentang perbankan Islam. Saini, Bick \& Abdulla (2011) menjelaskan bahwa beberapa pertimbangan masyarakat muslim memilih bank Islam adalah biaya transaksi murah, ketersediaan fasilitas transaksi perbankan, dan jaringan kantor bank. Sementara itu, Kishada \& Wahab (2013) menekankan peran penting manajer bank Islam dalam menarik minat nasabah dan menjadikanya sebagai nasabah loyal.

Penelitian ini memfokuskan pada faktor-faktor penentu dana pihak ketiga Bank Umum Syariah di Indonesia. Hal ini dilakukan untuk mengidentifikasi apakah bagi hasil, biaya promosi, dan jaringan kantor layanan berdampak signifikan terhadap dana pihak ketiga. Temuan penelitian ini dapat menjadi rujukan bagi bank umum syariah di Indonesia untuk mendorong peningkatan dana pihak ketiga melalui tingkat bagi hasil yang kompetitif, promosi yang berkelanjutan dan tepat sasaran, dan ketersediaan jaringan kantor layanan yang mudah diakses.

Gambar 1 menjelaskan perkembangan dana pihak ketiga bank umum syariah dari tahun 2010 - 2017 dapat dilihat bahwa 10 bank umum syariah tersebut rata-rata mengalami peningkatan dari tahun ke tahun. Peningkatan dana pihak ketiga memang terlihat tidak merata, ada yang meningkat tetapi ada juga nilai DPK yang cenderung fluktuatif. Pertumbuhan dana pihak ketiga dari tahun 2010 hingga tahun 2017 sebesar 69\% dengan kenaikan tertinggi yaitu dari tahun 2011 sebesar 34\%. Pertumbuhan dana pihak ketiga terendah ada pada tahun 2016 yaitu $0 \%$ atau stagnan.

Sementara itu, bagihasil bank umum syariah di Indonesia terus naik dari tahun 20102015 tetapi menurun pada tahun 2016 lalu meningkat pada tahun 2017. Pertumbuhan bagihasil dari tahun 2010 hingga 2017 secara keseluruhan cenderung naik dengan tingkat pertumbuhan $73,03 \%$. Namun demikian, tidak setiap tahun pertumbuhan tersebut mengalami peningkatan. Tingkat pertumbuhan tertinggi terjadi pada tahun 2011 yaitu sebesar 33\%. Tingkat pertumbuhan paling rendah terjadi pada tahun 2016 yaitu sebesar $11 \%$.

Jumlah kantor layanan yang terbanyak terjadi pada tahun 2014 yaitu sebanyak 2.133 unit tetapi menurun pada tahun 2017 hanya sebanyak 1.665 unit. Rata-rata pertumbuhan jumlah kantor layanan dari tahun 2010 hingga 2017 mencapai 28\%. Pertumbuhan tertinggi terjadi pada 2012 mencapai 20\%. Sementara itu, pertumbuhan terendah terjadi pada tahun 
2016 yaitu sebesar $-14 \%$. Ketersediaan kantor layanan ini juga dapat dicermati dari perkembangan biaya promosi untuk mengenalkan bank syariah kepada masyarakat. Pertumbuhan biaya promosi tertinggi terjadi pada tahun 2011 sebesar 34\%, sedangkan terendah terjadi pada tahun 2016 dengan tingka pertumbuhan $-27 \%$.

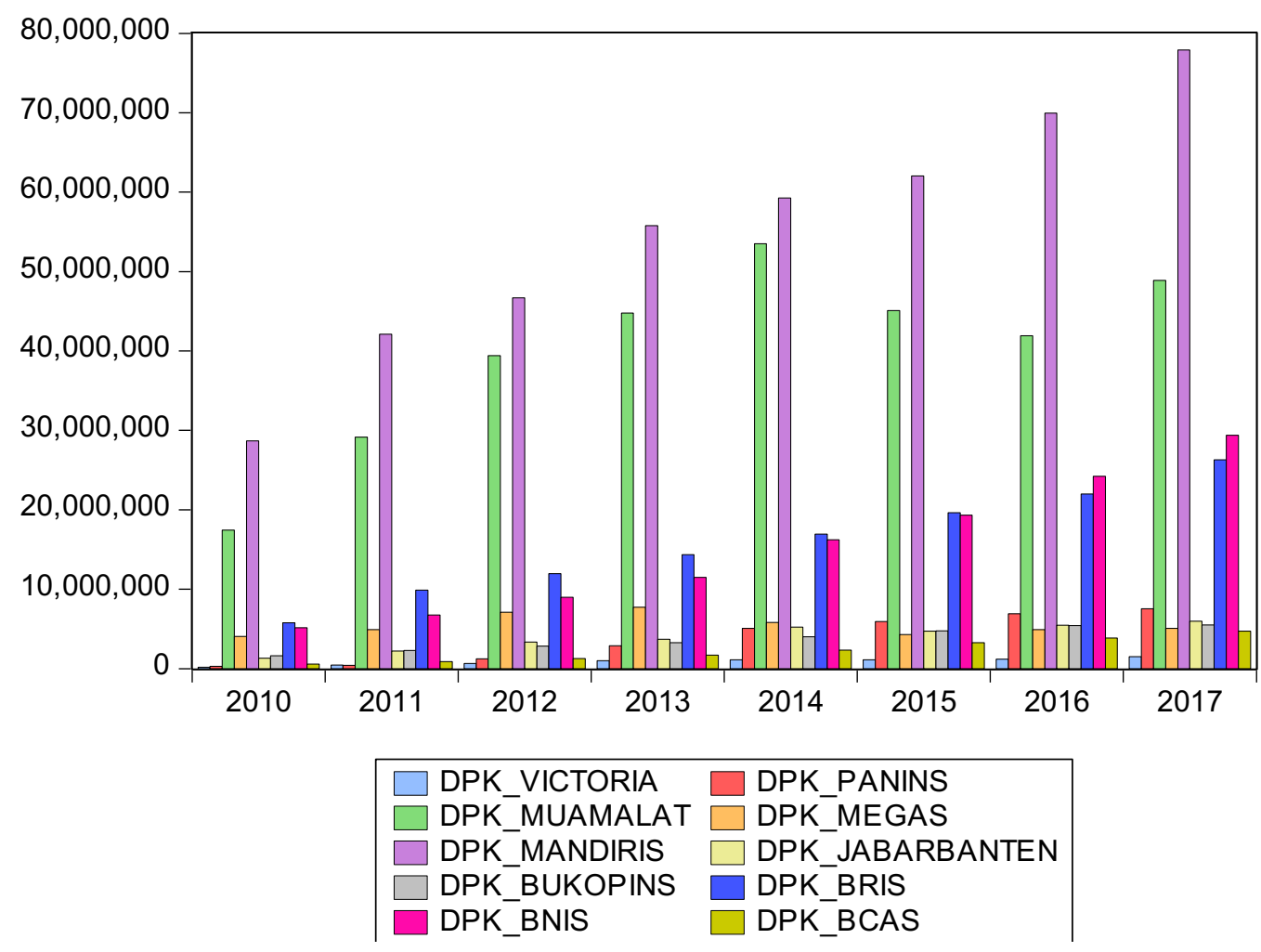

\section{Gambar 1. Perkembangan Dana Pihak Ketiga (DPK) 10 Bank Umum Syariah (BUS) Tahun 2010-2017 (dalam juta rupiah)}

Kontribusi penelitian meliputi hasil empiris yang membuktikan pengaruh signifikan bagi hasil, biaya promosi dan jumlah kantor layanan terhadap dana pihak ketiga BUS di Indonesia. Selain itu, penggunaan metode panel data terhadap 10 BUS dan 8 tahun menjadi keterbaharuan penelitian ini. Implikasinya adalah BUS sebaiknya mengkaji ulang strategi penetapan tingkat bagi hasil dan biaya promosi terhadap capaian DPK. Selain itu, jumlah kantor layanan sebaiknya dapat menjangkau masyarakat di luar area perkotaan sebagai salah satu strategi edukasi kepada masyarakat.

Pertanyaan penelitian ini terdiri atas tiga pertanyaan. Pertanyaan pertama adalah “Apakah bagi hasil berpengaruh terhadap dana pihak ketiga BUS di Indonesia?". Pertanyaan kedua adalah "Apakah biaya promosi berpengaruh terhadap dana pihak ketiga BUS di Indonesia?'. Pertanyaan ketiga adalah “Apakah jumlah kantor layanan berpengaruh terhadap dana pihak ketiga BUS di Indonesia?'.

Organisasi tulisan terdiri atas enam bagian. Bagian pertama adalah pendahuluan yang menjelaskan perkembangan variabel penelitian dan studi-studi empiris yang relevan. Bagian kedua adalah tinjauan pustaka yang membahas tentang teori dasar operasinal perbankan syariah termasuk undang-undang perbankan syariah dan studi-studi empiris yang relevan. Bagian ketiga adalah metode penelitian yang menjelaskan tentang model panel data. Bagian keempat adalah hasil dan pembahasan. Bagian kelima adalah simpulan. Sementara itu, bagian terakhir adalah referensi. 


\section{TINJAUAN PUSTAKA}

Berdasarkan Undang-undang No. 21 Tahun 2008 tentang Perbankan Syariah diketahui bahwa Pasal 1 Ayat 7 menyebutkan "Bank Syariah adalah Bank yang menjalankan kegiatan usahanya berdasarkan Prinsip Syariah dan menurut jenisnya terdiri atas Bank Umum Syariah dan Bank Pembiayaan Rakyat Syariah”. Sementara itu, Pasal 1 Ayat 8 menjelaskan bahwa "Bank Umum Syariah adalah Bank Syariah yang dalam kegiatannya memberikan jasa dalam lalu lintas pembayaran". Lebih lanjut Pasal 19 menjelaskan tentang kegiatan usaha bank syariah terdiri atas tiga pokok kegiatan yaitu penghimpunan dana masyarakat (dengan prinsip wadiah dan mudharabah), penyaluran dana langsung maupun tak langsung (jual beli, sewa dan investasi), dan jasa layanan (wakalah, hawalah, rahn dan kafalah).

Perbankan syariah dapat melakukan identifikasi terhadap faktor penentu nasabah menabung di bank syariah. Hal ini relevan dengan upaya perbankan syariah untuk meningkatkan nilai dana pihak ketiga. Sari, Wibowo \& Suprapto (2015) telah mengidentifikasi empat faktor penentu nasabah menabung di bank syariah, yaitu, faktor budaya, faktor sosial, faktor individu, dan faktor psikologis. Penelitian yang dilakukan disini tidak menggunakan faktor-faktor non-ekonomi tetapi menggunakan faktor bisnis yang menjadi komponen operasional BUS di Indonesia.

Pendekatan makroekonomi juga dapat digunakan untuk menginvestigasi faktor penentu dana pihak ketiga di perbankan syariah. Mobin \& Masih (2014) menyebutkan bahwa inflasi berdampak negatif dan signifikan terhadap deposito di perbankan syariah. Hal ini mengindisikan bahwa kebijakan makroekonomi yang mengarah pada stabilitas harga dengan tingkat inflasi rendah akan memberikan manfaat bagi peningkatan dana pihak ketiga di perbankan syariah. Penelitian yang dilakukan disini tidak menggunakan variabel-variabel makroekonomi dalam model estimasi data panel.

Prasetyoningrum (2015) menjelaskan bahwa BI Rate berpengaruh terhadap dana pihak ketiga di perbankan syariah. Selain itu, Lisa (2016) menyebutkan bahwa kemampuan penghimpunan dan distribusi dana perbankan terletak pada struktur modal dan dana pihak ketiga. Hal ini mengindikasikan bahwa keberadaan dana pihak ketiga menjadi penentu bagaimana operasional perbankan. Lebih lanjut, Yanti, Arfan \& Basri (2018) menemukan kecenderungan bahwa ada keterkaitan antara dana pihak ketiga dengan pembiayaan di perbankan syariah. Penelitian ini memfokuskan pada pengaruh bagi hasil, biaya promosi dan jumlah kantor layanan terhadap dana pihak ketiga BUS di Indonesia. Ada beberapa variabel yang tidak dimasukkan ke dalam model empiris data panel berdasarkan penelitian terdahulu tersebut yaitu, BI Rate, pembiayaan dan struktur modal.

\section{METODE PENELITIAN}

Fokus penelitian ini adalah Bank Umum Syariah (BUS) di Indonesia pada tahun 20102017. BUS tersebut yaitu : Bank Muamalat Indonesia; BNI Syariah; BRI Syariah; Bank Mandiri Syariah; Bank Victoria Syariah; Bank Jabar Banten Syariah; Bank Mega Syariah; Bank Panin Syariah; Bank Bukopin Syariah; dan BCA Syariah. Pemilihan 10 BUS tersebut didasarkan pada publikasi laporan keuangan Bank Umum Syariah yang ada pada situs resmi Bank Indonesia (www.bi.go.id) dan Otoritas Jasa Keuangan (www.ojk.go.id). Periode penelitian dimulai pada tahun 2010. Pemilihan ini disebabkan oleh ketersediaan publikasi dan kestabilan data yang telah dipublikasikan oleh Bank Indonesia maupun OJK dimulai pada tahun 2010. Selain itu, perkembangan bank umum syariah mulai terihat setelah lahirnya undang-undang resmi mengenai perbankan syariah tahun 2008 yang menyebabkan munculnya bank-bank syariah baru setelah undang undang tersebut ada. Sementara itu, periode akhir penelitian adalah tahun 2017. Hal ini disebabkan publikasi bank umum syariah oleh BI dan OJK terakhir adalah tahun 2017. 
Agusti Nia Aghnawati dan Malik Cahyadin : Faktor-Faktor Penentu Dana Pihak Ketiga Bank Umum Syariah Di Indonesia Tahun 2010-2017

Metode estimasi penelitian ini adalah data panel. Gujarati dan Porter (2009:636) mengatakan bahwa "panel data such as pooled data (pooling of time series and cross section observations), combination of time series and cross section data, micro panel data, longitudinal data, event history analysis, and cohort analysis". Model estimasi penelitian mengacu pada Wulandari dan Aisjah (2014), Mumtazah dan Septiarini (2016), dan Yulianto dan Solikhah (2016). Model dasar data panel yang digunakan adalah :

$$
\text { DPK }_{\text {it }}=\alpha_{1}+\beta_{1} \text { BAGIHASIL }_{i t}+\beta_{2} \mathrm{KL}_{\mathrm{it}}+\beta_{3} \text { PROMOSI }_{\mathrm{it}}+\mathrm{u}_{\mathrm{it}}
$$

DPK adalah dana pihak ketiga, BAGIHASIL adalah bagi hasil yang diberikan BUS kepada masyarakat, KL adalah jumlah kantor layanan yang dimiliki BUS, dan PROMOSI adalah biaya yang dikeluarkan BUS untuk mendukung capaian operasional BUS. $\alpha$ adalah konstanta, $\beta$ adalah koefisien regresi, I adalah 10 BUS (Bank Muamalat Indonesia, BNI Syariah, BRI Syariah, Bank Mandiri Syariah, Bank Victoria Syariah, Bank Jabar Banten Syariah, Bank Mega Syariah, Bank Panin Syariah, Bank Bukopin Syariah, BCA Syariah, t adalah tahun 2010-2017, sedangkan u adalah error term. Persamaan (1) disebut juga sebagai Common Effects Model (CEM).

Persamaan (1) dikonversi ke dalam logaritma sebagai berikut:

$\operatorname{LogDPK}_{i t}=\alpha_{1}+\beta_{1} \operatorname{LogBAGIHASIL}_{\mathrm{it}}+\beta_{2} \operatorname{LogKL}_{\mathrm{it}}+\beta_{3} \operatorname{LogPROMOSI}_{\mathrm{it}}+\mathrm{u}_{\mathrm{it}}$

Selain CEM, panel data juga terdiri atas fixed effects model (FEM) dan random effects model (REM). FEM disebut juga sebagai model Least-Squares Dummy Variable (LSDV). Persamaan FEM menambahkan variabel D (dummy) dalam model yang menjelaskan perbedaan intersep. Jumlah D adalah n-1 sebagai cerminan jumlah cross section dikurangi 1. Total cross-section adalah 10 BUS sehingga jumlah D adalah 9 BUS. Persamaan FEM dijelaskan oleh persamaan (3). Sementara itu, REM mengasumsikan bahwa $\alpha_{1}$ adalah random. Kita dapat menambahkan $\varepsilon$ sebagai random error sehingga term error dari REM adalah $\mathrm{w}$, dimana $\mathrm{w}=\varepsilon+\mathrm{u}$. Persamaan REM dapat dilihat pada persamaan (4).

$$
\begin{aligned}
& \operatorname{LogDPK}_{\mathrm{it}}=\alpha_{1}+\alpha 1 \mathrm{D}_{\mathrm{ni}}+\beta 1 \operatorname{LogBAGIHASILit}+\beta_{2} \operatorname{LogKL}_{\mathrm{it}}+\beta_{3} \operatorname{LogPROMOSI}_{\mathrm{it}}+\mathrm{u}_{\mathrm{it}} \\
& \operatorname{LogDPK}_{\mathrm{it}}=\alpha_{1}+\beta_{1} \operatorname{LogBAGIHASIL}_{\mathrm{it}}+\beta_{2} \operatorname{LogKL}_{\mathrm{it}}+\beta_{3} \operatorname{LogPROMOSI}_{\mathrm{it}}+\mathrm{w}_{\mathrm{it}}
\end{aligned}
$$

\section{HASIL DAN PEMBAHASAN}

Analisis data panel meliputi metode common effects model (CEM), fixed effects model (FEM), dan random effects model (REM). Prosedur untuk menentukan salah satu metode terbaik dapat dilakukan dengan uji Chow, Hausman, dan Lagrange Multiplier. Hasil ketiga uji tersebut menunjukkan bahwa metode terbaik estimasi penelitian ini adalah REM (lihat lampiran).

Table 1 menjelaskan hasil estimasi data panel dengan REM. Nilai $t$-statistics variabel bagi hasil yaitu sebesar 11,72690. Hal ini menunjukkan bahwa t-statistikc lebih besar dari ttabel $(11,72690>1,671)$ dengan $\alpha=0,05$. Dengan demikian, dapat disimpulkan bahwa bagi hasil berpengaruh signifikan terhadap dana pihak ketiga. Nilai $t$-statistics jumlah kantor layanan adalah sebesar 4,171154 dengan $\alpha=0,05$ dihasilkan nilai t-tabel sebesar 1,671. Artinya bahwa variabel kantor layanan berpengaruh signifikan terhadap dana pihak ketiga bank umum syariah.

Temuan penelitian ini menunjukkan hasil estimasi yang lebih tepat dibandingkan dengan hasil studi empiris sebelumnya. Misalnya, variabel makroekonomi hanya inflasi yang berpengaruh terhadap deposito di perbankan syariah (Mobin \& Masih, 2014). 
Sementara itu, Novianto \& Hadiwidjojo (2013) mengidentifikasi bahwa PDB berpengaruh terhadap dana pihak ketiga bank umum syariah.

Hasil penelitian ini tidak relevan dengan temuan Novianto \& Hadiwidjojo (2013) bahwa bagi hasil tidak signifikan. Namun demikian, penelitian ini relevan dengan hasil penelitian yang dilakukan oleh Mumtazah \& Septiarini (2016) bahwa biaya promosi berpengaruh terhadap dana pihak ketiga bank umum syariah. Lebih lanjut, penelitian ini juga relevan dengan penelitian Prasetya, Tan \& Delis (2015), dan Novianto \& Hadiwidjojo (2013) bahwa jumlah kantor layanan berpengaruh terhadap tingkat dana pihak ketiga bank umum syariah. Namun demikian, penelitian ini tidak relevan dengan penelitian yang dilakukan oleh Wulandari \& Aisjah (2014) bahwa jumlah kantor layanan tidak berpengaruh terhadap dana pihak ketiga bank umum syariah.

Tabel 1. Hasil Estimasi Panel Menggunakan Random Effect Model

\begin{tabular}{ccccc}
\hline Variabel & Koefisien & Std. Error & t-Statistic & Probabilitas \\
\hline C & 3,058300 & 0,186158 & $16,42848^{* *}$ & 0,0000 \\
LogBAGIHASIL & 0,482362 & 0,041133 & $11,72690^{* *}$ & 0,0000 \\
LogKL & 0,282282 & 0,067675 & $4,171154^{* *}$ & 0,0001 \\
LogPROMOSI & 0,158681 & 0,057893 & $2,740937^{* *}$ & 0,0076 \\
R-squared & 0,874755 & & & \\
Adjusted R-squared & 0,869811 & & & \\
F-statistic & 176,9366 & & & 0,000000 \\
\hline
\end{tabular}

Keterangan:

a) Variabel dependen $=$ Log Dana Pihak Ketiga

b) ${ }^{*} \alpha=1 \%, * * \alpha=5 \%, * * * \alpha=10 \%$

Selanjutnya, Nilai $t$-statistics biaya promosi yaitu sebesar 2,740937 dengan $\alpha=0,05$ dihasilkan nilai t-tabel sebesar 1,671. Dengan demikian, dapat dinyatakan bahwa variabel promosi berpengaruh signifikan terhadap dana pihak ketiga bank umum syariah. Temuan penelitian ini relevan dengan penelitian yang dilakukan oleh Mumtazah \& Septiarini (2016) bahwa biaya promosi berpengaruh terhadap dana pihak ketiga bank umum syariah.

Nilai F-statistik yaitu sebesar 176,9366, dimana F-tabel adalah sebesar 1,671. Hal ini dapat disimpulkan bahwa F-statistik lebih besar daripada F-tabel $(176,9366>2,73)$ maka Ho ditolak. Artinya bahwa variabel Jumlah Kantor Layanan Bagi Hasil, dan Biaya Promosi berpengaruh terhadap dana pihak ketiga bank umum syariah secara bersama-sama pada tahun 2010-2017. Dengan demikian, model estimasi REM telah menunjukkan ketepatan estimasi faktor penentu dana pihak ketiga BUS di Indonesia.

Nilai koefisien determinasi $\mathrm{R}^{2}$ (adjusted $\mathrm{R}^{2}$ ) sebesar 0.869811 atau $86.9811 \%$. Hal ini menunjukkan bahwa jumlah kantor, bagi hasil, dan biaya promosi berpengaruh $86.9811 \%$ terhadap total dana pihak ketiga bank umum syariah. Sementara itu, sebesar $13.0189 \%$ dana pihak ketiga dipengaruhi oleh variabel di luar model. Hal ini mengindikasikan bahwa model estimasi REM telah layak (robust) digunakan sebagai generalisasi bahwa bagi hasil, biaya promosi dan jumlah kantor layanan berpengaruh signifikan terhadap dana pihak ketiga BUS di Indonesia.

\section{SIMPULAN}

Hasil estimasi REM menjelaskan bahwa bagi hasil berpengaruh signifikan dan positif terhadap dana pihak ketiga bank umum syariah di Indonesia tahun 2010 - 2017. Hal ini menunjukkan bahwa besar kecilnya bagi hasil yang diberikan bank umum syariah kepada masyarakat akan berpengaruh dengan besar kecilnya dana masuk dari masyarakat yang dititipkan di investikan pada bank umum syariah tersebut. 
Agusti Nia Aghnawati dan Malik Cahyadin : Faktor-Faktor Penentu Dana Pihak Ketiga Bank Umum Syariah Di Indonesia Tahun 2010-2017

Hasil estimasi kedua bahwa jumlah kantor layanan memiliki pengaruh yang signifikan dan positif terhadap dana pihak ketiga. Hal ini menunjukkan bahwa semakin banyaknya kantor layanan bank umum syariah maka semakin banyak dana pihak ketiga yang masuk pada BUS tersebut karena masyarakat akan semakin mudah menjangkaunya.

Sementara itu, hasil estimasi ketiga menjelaskan bahwa biaya promosi memiliki pengaruh yang signifikan dan positif terhadap dana pihak ketiga. Hal ini menunjukkan bahwa semakin banyak promosi yang diberikan akan semakin mengenalkan produk bank umum syariah kepada masyarakat sehingga akan menambah ketertarikan dan kepercayaan masyarakat untuk menabung di Bank Umum Syariah.

Rekomendasi penelitian ini adalah Bank Umum Syariah sebaiknya menetapkan bagihasil yang kompetitif untuk menarik minat masyarakat menabung. Bank Umum Syariah juga dapat meningkatkan alokasi dana promosi untuk melakukan sosialisasi dan kerjasama dengan berbagai pihak dalam rangka meningkatkan dana pihak ketiga. Selain itu, penambahan jumlah jaringan kantor layanan juga perlu dipertimbangkan untuk basis-basis masyarakat muslim di berbagai wilayah di Indonesia.

\section{DAFTAR PUSTAKA}

Gujarati, D. N. \& Porter, D. C. 2009. Basic Econometric 5th Edition. New York : McGraw Hill.

Hilman, I. 2016. The Factors Affecting Mudharabah Deposits of Sharia Banking in Indonesia. International Journal of Business and Management Invention. 5 (8): 56-66.

Kishada, Z. M.E.M. \& Wahab, N. A. 2013. Factors Affecting Customer Loyalty in Islamic Banking: Evidence from Malaysian Banks. International Journal of Business and Social Science. 4 (7): 264-273.

Lisa, O. 2016. Analysis of Effect of Capital Structure, Company Size and Distribution of Funds against Third Party Financing and Its Implication on Profitability (Studies in Islamic Cooperative Baitul Maal Tamwil in Indonesia). International Journal of Finance and Accounting. 5 (3): 158-164

Mobin, M. A. \& Masih, M. 2014. Do the Macroeconomic Variables have any Impact on the Islamic Bank Deposits? An Application of ARDL Approach to the Malaysian Market. MPRA Paper No. 623342 February. https://mpra.ub.uni-muenchen.de/62342/

Mumtazah, W. \& Septiarini, D. F. 2016. Analisis Faktor-Faktor yang Mempengaruhi Jumlah Dana Pihak Keriga Pada Bank Umum Syariah di Indonesia (Periode Triwulan I 2010 - Triwulan 1 2015). Surabaya : Universitas Airlangga.

Novianto, A. S. \& Hadiwidjojo, D. 2013. Analisis Faktor-Faktor yang Mempengaruhi Penghimpunan Deposito Mudharabah Perbankan Syariah di Indonesia. Jurnal Aplikasi Manajemen. 11 (4): 595-604.

Prasetya, B., Tan, S. \& Delis, A. 2015. Faktor-Faktor yang Mempengaruhi Penghimpunan Dana Pihak Ketiga Perbankan Syariah di Indonesia. Jurnal Perspektif Pembiayaan dan Pembangunan Daerah. 3 (2): 91-100.

Prasetyoningrum, A. K. 2015. Analysis BI Rate and Return of Third Party Fund on Rate of Third Party Fund on Islamic Banking in Indonesia. Conference In Business, Accounting, And Management (CBAM), 2, 1, 104-116.

Saini, Y., Bick, G. \& Abdulla, L. 2011. Consumer Awareness and Usage of Islamic Banking Products in South Africa. SAJEMS. 14 (3): 298-313.

Sari, I. M., Wibowo, H. \& Suprapto, E. 2015. Factors that Influenced People to Become Islamic Bank Customer: A Study on Kancana Villagers. Al-Iqtishad. VII (1): 73-86.

Sudarsono, H. 2009. Dampak Krisis Keuangan Global terhadap Perbankan di Indonesia: Perbandingan antara Bank Konvensional dan Bank Syariah. Jurnal Ekonomi Islam La Riba. III (1): 12-23. 
Undang-undang No. 21 Tahun 2008 tentang Perbankan Syariah.

Wulandari, S. \& Siti, A. 2014. Analisis Faktor Internal dan Eksternal Yang Mempengaruhi Total Dana Pihak Ketiga (DPK) Bank Umum Syariah di Indonesia (Studi pada Bank Umum Syariah Periode 2011-2013). Malang: Universitas Brawijaya.

Yanti, E. M., Arfan, M. \& Basri, H. 2018. The Effect of Third Party Funds, Financing to Deposit Ratio and Non Performing Financing toward Financing and its Impact on Profitability of Indonesian Sharia Banking (Studies at Sharia Commercial Banks Period 2011-2015). Account and Financial Management Journal. 3 (01) 1240-1246.

Yulianto, A. \& Solikhah, B. 2016. The Internal Factors of Indonesian Sharia Banking to Predict the Mudharabah Deposits. Review of Integrative Business \& Economics Research. 5 (1): 210-218. 


\section{Lampiran}

Lampiran 2. Hasil Uji Hausman

\begin{tabular}{cccc}
\hline \multicolumn{4}{c}{ Correlated Random Effect - Hausman Test } \\
& Test Cross-section Random Effect \\
\hline Test Summary & Chi - Sq. Statistic & Chi - Sq. & Prob \\
Cross - section & 2,413203 & D.f & \\
Random & & 3 & 0,4912 \\
Sumber: Output of Eviews 9 & & & \\
\end{tabular}

Lampiran 3. Hasil Uji Lagrange Multiplier

Lagrange Multiplier (LM) test for panel data

Null (no rand. effect) Cross-section

Alternative One-sided

Breusch-Pagan

22.93221

$(0.0000)$

Sumber: Output of Eviews 9

Lampiran 4. Hasil Estimasi Common Effects Model

Dependent Variabel: LOGDPK?

Method: Pooled Least Squares

Sample: 20102017

Included observations: 8

Cross-sections included: 10

Total pool (balanced) observations: 80

\begin{tabular}{crrrr}
\hline \hline \multicolumn{1}{c}{ Variabel } & Coefficient & Std. Error & t-Statistic & Prob. \\
\hline \hline C & 3.144945 & 0.298679 & 10.52952 & 0.0000 \\
LOGBAGIHASIL? & 0.467797 & 0.082027 & 5.702980 & 0.0000 \\
LOGKL? & 0.533497 & 0.061850 & 8.625696 & 0.0000 \\
LOGPROMOSI? & 0.032325 & 0.066148 & 0.488675 & 0.6265 \\
\hline \hline R-squared & 0.874780 & Mean dependent var & 6.791300 \\
Adjusted R-squared & 0.869837 & S.D. dependent var & 0.621770 \\
S.E. of regression & 0.224323 & Akaike info criterion & -0.102755
\end{tabular}




\begin{tabular}{lllr} 
Sum squared resid & 3.824372 & Schwarz criterion & 0.016346 \\
Log likelihood & 8.110209 & Hannan-Quinn criter. & -0.055004 \\
F-statistic & 176.9773 & Durbin-Watson stat & 0.266257 \\
Prob(F-statistic) & 0.000000 & & \\
\hline \hline
\end{tabular}

Sumber: Output of Eviews 9

Lampiran 5. Hasil Estimasi Fixed Effects Model

Dependent Variabel: LOGDPK?

Method: Pooled Least Squares

Sample: 20102017

Included observations: 8

Cross-sections included: 10

Total pool (balanced) observations: 80

\begin{tabular}{|c|c|c|c|c|}
\hline Variabel & Coefficient & Std. Error & t-Statistic & Prob. \\
\hline $\mathrm{C}$ & 3.067850 & 0.174127 & 17.61848 & 0.0000 \\
\hline LOGBAGIHASIL? & 0.487567 & 0.041757 & 11.67631 & 0.0000 \\
\hline LOGKL? & 0.244045 & 0.072195 & 3.380354 & 0.0012 \\
\hline LOGPROMOSI? & 0.167484 & 0.060642 & 2.761827 & 0.0074 \\
\hline \multicolumn{5}{|l|}{ Fixed Effects (Cross) } \\
\hline MUAMALAT_C & 0.034471 & & & \\
\hline _VICTORIA-C & -0.153940 & & & \\
\hline BRIS-C & -0.042117 & & & \\
\hline \multicolumn{5}{|l|}{ JABA- RBANTEN- } \\
\hline $\mathrm{C}$ & -0.159869 & & & \\
\hline $\mathrm{BNIS}-\mathrm{C}$ & -0.051269 & & & \\
\hline _MANDIRI-C & 0.651109 & & & \\
\hline MEGA-C & -0.237154 & & & \\
\hline PANIN_C & 0.054181 & & & \\
\hline$\overline{\mathrm{BU}} \mathrm{COPIN}-\mathrm{C}$ & -0.041994 & & & \\
\hline \multirow[t]{2}{*}{$-\mathrm{BCA}-\mathrm{C}$} & -0.053419 & & & \\
\hline & \multicolumn{4}{|c|}{ Effects Specification } \\
\hline \multicolumn{5}{|c|}{ Cross-section fixed (dummy variabels) } \\
\hline R-squared & 0.978464 & \multicolumn{2}{|c|}{ Mean dependent var } & 6.791300 \\
\hline Adjusted R-squared & 0.974607 & \multicolumn{2}{|c|}{ S.D. dependent var } & 0.621770 \\
\hline S.E. of regression & 0.099080 & \multicolumn{2}{|c|}{ Akaike info criterion } & -1.638120 \\
\hline Sum squared resid & 0.657724 & \multicolumn{2}{|c|}{ Schwarz criterion } & -1.251041 \\
\hline Log likelihood & 78.52479 & \multicolumn{2}{|c|}{ Hannan-Quinn criter. } & -1.482929 \\
\hline F-statistic & 253.6773 & \multicolumn{2}{|c|}{ Durbin-Watson stat } & 1.194922 \\
\hline Prob(F-statistic) & 0.000000 & & & \\
\hline
\end{tabular}

Sumber: Output of Eviews 9 
Lampiran 6. Hasil Estimasi Random Effects Model

Dependent Variabel: LOGDPK?

Method: Pooled EGLS (Cross-section random effects)

Sample: 20102017

Included observations: 8

Cross-sections included: 10

Total pool (balanced) observations: 80

Swamy and Arora estimator of component variances

\begin{tabular}{crrrr}
\hline \hline Variabel & Coefficient & Std. Error & t-Statistic & Prob. \\
\hline \hline C & 3.058300 & 0.186158 & 16.42848 & 0.0000 \\
LOGBAGIHASIL? & 0.482362 & 0.041133 & 11.72690 & 0.0000 \\
LOGKL? & 0.282282 & 0.067675 & 4.171154 & 0.0001 \\
LOGPROMOSI? & 0.158681 & 0.057893 & 2.740937 & 0.0076 \\
Random Effects & & & & \\
(Cross) & & & & \\
_MUAMALAT--C & 0.021942 & & & \\
_ VICTORIA--C & -0.137760 & & & \\
BRIS--C & -0.049800 & & & \\
JABARBANTEN- & & & \\
C & -0.148456 & & & \\
BNIS--C & -0.055318 & & & \\
_MANDIRI--C & 0.605311 & & & \\
_MEGA--C & -0.248764 & & & \\
PANIN--C & 0.077811 & & & \\
BUKOPIN--C & -0.021851 & & & \\
_BCA--C & -0.043113 & & & \\
\hline \hline
\end{tabular}

Effects Specification

\begin{tabular}{|c|c|c|c|}
\hline & & S.D. & Rho \\
\hline Cross-section random & & 0.246495 & 0.8609 \\
\hline Idiosyncratic random & & 0.099080 & 0.1391 \\
\hline \multicolumn{4}{|c|}{ Weighted Statistics } \\
\hline R-squared & 0.874755 & \multirow{4}{*}{$\begin{array}{l}\text { Mean dependent var } \\
\text { S.D. dependent var } \\
\text { Sum squared resid } \\
\text { Durbin-Watson stat }\end{array}$} & 0.955525 \\
\hline Adjusted R-squared & 0.869811 & & 0.273536 \\
\hline S.E. of regression & 0.098696 & & 0.740314 \\
\hline F-statistic & 176.9366 & & 1.073172 \\
\hline Prob(F-statistic) & \multicolumn{2}{|l|}{0.000000} & \\
\hline \multicolumn{4}{|c|}{ Unweighted Statistics } \\
\hline R-sC & 0.846497 & Mean dependent var & 6.791300 \\
\hline Sum squared resid & 4.688179 & Durbin-Watson stat & 0.169465 \\
\hline
\end{tabular}

Sumber: Output of Eviews 9 